\title{
The Mechanism and Application of Deep-Hole Precracking Blasting on Rockburst Prevention
}

\author{
Zhenhua Ouyang, ${ }^{1,2}$ Qingxin Qi, ${ }^{1,2}$ Shankun Zhao, ,2 Baoyang Wu, ${ }^{1,2}$ and Ningbo Zhang ${ }^{1,2}$ \\ ${ }^{1}$ China Coal Research Institute, Beijing 100013, China \\ ${ }^{2}$ State Key Laboratory of Coal Mining and Clean Energy Utilization, Beijing 100013, China \\ Correspondence should be addressed to Zhenhua Ouyang; oyzhua@163.com
}

Received 13 November 2014; Revised 18 January 2015; Accepted 8 February 2015

Academic Editor: Marcin A. Lutynski

Copyright ( 2015 Zhenhua Ouyang et al. This is an open access article distributed under the Creative Commons Attribution License, which permits unrestricted use, distribution, and reproduction in any medium, provided the original work is properly cited.

\begin{abstract}
The mechanism of preventing rockburst through deep-hole precracking blasting was studied based on experimental test, numerical simulation, and field testing. The study results indicate that the deep-hole precracking could change the bursting proneness and stress state of coal-rock mass, thereby preventing the occurrence of rockburst. The bursting proneness of the whole composite structure could be weakened by the deep-hole precracking blasting. The change of stress state in the process of precracking blasting is achieved in two ways: (1) artificially break the roof apart, thus weakening the continuity of the roof strata, effectively inducing the roof caving while reducing its impact strength; and (2) the dynamic shattering and air pressure generated by the blasting can structurally change the properties of the coal-rock mass by mitigating the high stress generation and high elastic energy accumulation, thus breaking the conditions of energy transfer and rock burst occurrence.
\end{abstract}

\section{Introduction}

Rockburst is one of the major dynamic disasters in mining, tunneling, and other underground engineering since it causes numerous casualties and accidents in South Africa, Central Europe, North and South America, China, and other countries of the world. Since the first rockburst which occurred at Shengli coal mine in Fushun and was recorded in 1933, over 3,000 coal bursts had happened in nearly 140 coal mines in China over the past 80 years. Rockbursts and their secondary disasters have been associated with thousands of accidents and casualties. For instance, on June 5, 2008, November 3, 2011, and March 27, 2014, three serious rockbursts accidents happened in Qianqiu coal mine of Yima Coal Industry Group, killing a total of 29 people and injuring more than 80 people. Also, on February 14, 2005, 214 workers were killed in a gas explosion disaster induced by rockburst in Sunjiawan coal mine in Fuxin, Liaoning Province. Rockburst has become one of the major dynamic disasters in deep coal mining in China.

As of now, understanding of rockburst mechanism is not explicit because of so many uncertain factors such as bursting proneness of coal and rock stratum, geological conditions, and mining technology. Over the years, many studies pertinent to evaluation [1-3], prediction, and prevention of rockbursts have been conducted. To effectively predict rockburst, various methods and/or models have been established, including fuzzy comprehensive evaluation method [4, 5], Bayes' discriminant analysis [6], unascertained measurement approach [7], Lyapunov index method [8], maximum entropy principle [9], rough set combined with genetic algorithm [10], judgment index classification [11], stress state determination [12], rough set theory [13], mining and seismological parameters [14-16], and optimal relative membership degree [9]. In the field, methods and measures of optimal mining layout, mining protection layer, coal seam water injection, hydraulic fracturing [17], destress blasting [18-20], rock blasting [2124], deep-hole directional fracturing [25], destress drilling, and deep-hole precracking blasting, and so forth, have been developed and applied for burst prevention.

Deep-hole precracking blasting (DHPB) is conceptually defined as blasting in the coal-rock mass with a blast hole with a depth of more than $10 \mathrm{~m}$ to develop fractures in the coal-rock mass. A coal seam with thick hard roof strata, such 


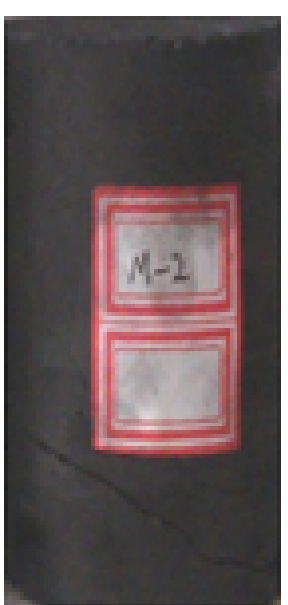

(a) Pure coal

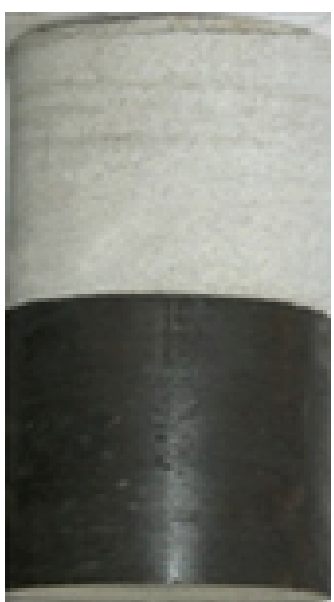

(b) $1: 1$ coal-rock mass complex

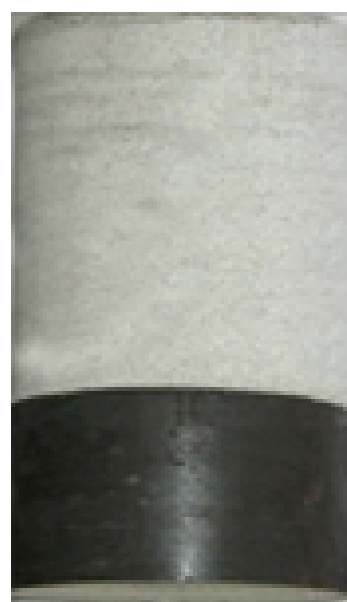

(c) $1: 2$ coal-rock mass complex

FIGURE 1: The bursting proneness test samples of coal-rock mass combination.

as Qianqiu mine of Yima Coal Industry Group and Huafeng coal mine of Xinwen Mining Group, uncaved roof strata in mined-out area could accumulate energy and incur potential rockburst. When adopting the approach of DHPB, the integrality and continuity of roof can be directly broken. As a simple process and effective rockburst preventing measure, it has been widely used in these burst-prone coal mines in China. To further study the rockburst mechanism of DHPB, experimental test, numerical simulation, and field testing were conducted and corresponding results were presented in this paper.

\section{The Influence of DHPB on the Bursting Proneness of Coal-Rock Mass}

2.1. Bursting Proneness Test of "Roof-Coal" Combination. The bursting proneness is an inherent property of coal-rock mass incurring bursting damage. In order to compare and study the bursting proneness of "roof-coal" combination, samples of roof stratum only, coal only, and two "roof-coal" combinations were tested with TAW-2000 microcomputer-controlled electrohydraulic servo rock triaxial testing machine in the lab. Figure 1 illustrates these three classified samples utilized in the test. Both roof rock and coal were taken from Yuejin coal mine of Yima Coal Industry Group and the samples of "roofcoal" combinations are glued together with columns of coal and roof rock. The finished cylindrical test specimens were about $50 \mathrm{~mm}$ in diameter and $100 \mathrm{~mm}$ in height.

The bursting proneness measurements of roof strata were conducted by following the Chinese national recommended standard GB/T25217.1-2010, which is named "Methods of test, monitoring and prevention of rockburst-part 1: Classification and laboratory test method on bursting liability of roof strata." In this standard, bending energy index was express appointed to determine and evaluate the bursting proneness of roof strata, just as Table 1 listed.
TABLE 1: Classification of bursting proneness of coal.

\begin{tabular}{lccc}
\hline Classification & Type I & Type II & Type III \\
\hline Bursting proneness & None & Weak & Strong \\
\hline $\begin{array}{l}\text { Bending energy } \\
\text { index }\left(U_{\mathrm{WQS}}\right) / \mathrm{kJ}\end{array}$ & $U_{\mathrm{WQS}} \leq 15$ & $15<U_{\mathrm{WQS}} \leq 120$ & $U_{\mathrm{WQS}}>120$ \\
\hline
\end{tabular}

The bursting proneness measurements of coal and "roofcoal" combinations were conducted by following the Chinese national recommended standard GB/T25217.2-2010, which is named "Methods of test, monitoring and prevention of rockburst-part 2: Classification and laboratory test method on bursting liability of coal." To determine and evaluate the bursting proneness of coal, four indexes, including duration of dynamic fracture $(D T)$, elastic strain energy $\left(W_{\mathrm{ET}}\right)$, bursting energy $\left(K_{E}\right)$, and uniaxial compressive strength $\left(R_{c}\right)$, were utilized in the testing and analysis. The classification of bursting proneness of coal is listed in Table 2.

2.2. Bursting Proneness Testing Results and Analysis. Based on measured uniaxial compressive strength, tensile strength, density, and elastic modulus of the roof stratum, the bending energy index of the roof was calculated as $22.09 \mathrm{~kJ}$, which indicates that the bursting proneness of the roof stratum is weak.

Table 3 indicates sample group numbering, values of these four indexes of coal, and corresponding bursting proneness. Groups A, B, and C in Table 2 represent samples of coal, 1:1 coal-rock mass complex sample, and 1:2 coal-rock complex sample, respectively. The testing and calculation results indicate that the bursting proneness of these three group samples $\mathrm{A}, \mathrm{B}$, and $\mathrm{C}$ are weak, weak, and strong, respectively.

As indicated in Table 2, with the increase of roof stratum volume, the duration time of dynamic damage of the sample deceased, but the bursting energy, elastic energy, and uniaxial 
TABLE 2: Classification of bursting proneness of coal.

\begin{tabular}{lccc}
\hline Classification & Type I & Type II & Type III \\
\hline Bursting proneness & None & Weak & Strong \\
Indexes & & & $D T \leq 50$ \\
$\quad$ & $D T>500$ & $50<D T \leq 500$ & $W_{\mathrm{ET}} \geq 5$ \\
Duration of dynamic fracture $(D T) / \mathrm{ms}$ & $W_{\mathrm{ET}}<2$ & $2 \leq W_{\mathrm{ET}}<5$ & $K_{E} \geq 5$ \\
Elastic strain energy index $\left(W_{\mathrm{ET}}\right)$ & $K_{E}<1.5$ & $1.5 \leq K_{E}<5$ & $R_{c} \geq 14$ \\
Bursting energy index $\left(K_{E}\right)$ & $R_{c}<7$ & $7 \leq R_{c}<14$ & \\
Uniaxial compressive strength $\left(R_{c}\right) / \mathrm{MPa}$ & &
\end{tabular}

TABLE 3: Bursting proneness testing results of coal and coal-rock mass combination.

\begin{tabular}{lccccl}
\hline $\begin{array}{l}\text { Sample } \\
\text { number }\end{array}$ & $D T / \mathrm{ms}$ & $K_{E}$ & $W_{\mathrm{ET}}$ & $R_{c} / \mathrm{MPa}$ & $\begin{array}{l}\text { Bursting } \\
\text { proneness degree }\end{array}$ \\
\hline A-1 & 316 & 1.44 & 3.10 & 10.08 & \\
A-2 & 358 & 1.55 & 2.37 & 13.64 & Weak \\
A-3 & 379 & 1.93 & 2.41 & 15.21 & \\
Average & $\mathbf{3 5 1}$ & $\mathbf{1 . 6 4}$ & $\mathbf{2 . 6 3}$ & $\mathbf{1 2 . 9 8}$ & \\
\hline B-1 & 218 & 2.06 & 5.49 & 15.89 & \\
B-2 & 132 & 3.82 & 2.74 & 16.98 & Weak \\
B-3 & 150 & 2.57 & 3.52 & 15.96 & \\
Average & $\mathbf{1 6 6}$ & $\mathbf{2 . 8 2}$ & $\mathbf{3 . 9 2}$ & $\mathbf{1 6 . 2 8}$ & \\
\hline C-1 & 16 & 7.83 & 6.62 & 17.26 & \\
C-2 & 8 & 10.83 & 4.50 & 21.23 & Strong \\
C-3 & 13 & 9.68 & 5.87 & 19.12 & \\
Average & $\mathbf{1 2 . 3}$ & $\mathbf{9 . 4 4}$ & $\mathbf{5 . 5 3}$ & $\mathbf{1 9 . 2 0}$ & \\
\hline
\end{tabular}

compressive strength increased. When volume of roof stratum in the sample is two times large as the coal, the bursting proneness of the coal-rock mass became strong. It suggests that the roof stratum has a great influence on the bursting proneness of the coal seam. Although the bursting proneness of samples in Groups A and B is considered as weak, the average bursting proneness of coal-rock mass is greater than that of pure coal.

2.3. The Impact of DHPB on the Bursting Proneness of RoofCoal Mass. As mentioned above, the roof stratum has a great impact on the bursting proneness of the coal seam. When assessing the bursting proneness of a specific coal mine merely using the bursting proneness result from a single seam or rock layer, the assessment result might lead to be conservative. The actual degree of bursting proneness of the coal seam in the active working, which is actually determined by the combination of roof strata and coal seam, is greater than that obtained from the lab testing. The lab testing results above indicate that the bursting proneness of the coal mass is actually greater with the increase of roof strata in the reality.

When applying the approach of DHPB, the integrity and continuity between the roof strata and coal seam are structurally broken, thus weakening and/or reducing their bursting proneness.

\section{The Influence of DHPB on Changing Stress State}

3.1. Numerical Simulation of DHPB. Based on the geotechnical condition of working face 25110 of Yuejin coal mine, the numerical analysis software FLAC was utilized to simulate the influence of DHPB on stress distribution in coal-rock mass.

The mechanical properties of coal-rock used in the numerical model are listed in Table $4 . H$ is the thickness of the coal-rock strata, $\mathrm{m} ; \rho$ is the density, $\mathrm{kg} \cdot \mathrm{m}^{-3} ; C$ is the adhesion stress, $\mathrm{MPa} ; \phi$ is the internal friction angle, ${ }^{\circ} ; G$ is the bulk modulus, GPa; $E$ is the shear modulus, GPa; and $\sigma_{c}$ is the tensile strength, MPa. The simulation of the blasting influence on the coal-rock mass was achieved by weakening the mechanical property values of the coal-rock mass within the influencing area of the roof blasting, including density, elastic modulus, Poisson's ratio, tensile strength, cohesion, and frictional angle. There are multiple factors influencing the results of DHPB, such as blast hole angle, sealing length, and explosive dose. In this model, the depth and sealing length of the blasting hole are $20 \mathrm{~m}$ and $10 \mathrm{~m}$, respectively. The blasting hole angles of $30^{\circ}, 45^{\circ}$, and $60^{\circ}$ were successively applied in the model as a comparison.

3.2. Numerical Simulation Results and Analysis. There are four cases simulated in this study.

(i) Case-1: no blasting hole.

(ii) Case-2: blasting angle is $30^{\circ}$.

(iii) Case-3: blasting angle is $45^{\circ}$.

(iv) Case-4: blasting angle is $60^{\circ}$.

Figure 2 indicates the distribution and change of the side-abutment pressure of these four cases. The numerical modeling results indicate that the peak side-abutment pressure is $83.7 \mathrm{MPa}$ when not deploying precracking blasting. When applying the precracking blasting in the model, the peak side-abutment pressure decreases as the hole angle increases from $30^{\circ}$ to $60^{\circ}$ with decrements of $24.0 \%, 15.5 \%$, and $9.2 \%$ as comparing with Case-1. In other words, the stress magnitude developed in the coal-rock mass can be effectively reduced/relieved by the precracking blasting with the effective blasting range. The degree of the stress reduction is mainly determined by the blasting hole angle when the rest of the parameters remain the same.

Furthermore, the main influences of DHPB on coal-rock mass stress environment can be summarized as follows. 
TABLE 4: The physical and mechanics properties of rock layers in numerical simulation.

\begin{tabular}{lccccccc}
\hline Rock layers & $H / \mathrm{m}$ & $\rho / \mathrm{kg}^{-\mathrm{m}^{-3}}$ & $C / \mathrm{MPa}$ & $\phi /^{\circ}$ & $G / \mathrm{GPa}$ & $E / \mathrm{GPa}$ & $\sigma_{c} / \mathrm{MPa}$ \\
\hline Roof sandstone & 40 & 2550 & 17 & 35 & 12 & 4.9 & 11 \\
Roof mudstone & 20 & 2700 & 13.5 & 29.2 & 8.2 & 7.8 & 1.5 \\
Coal seam & 10 & 1400 & 9 & 26.9 & 1.7 & 12.6 \\
Backplane mudstone & 4 & 2500 & 13.8 & 29.5 & 12.8 & 10 & 4.6 \\
Backplane sandstone & 26 & 2500 & 16.4 & 30.8 & 12.1 & 11.9 \\
\hline
\end{tabular}

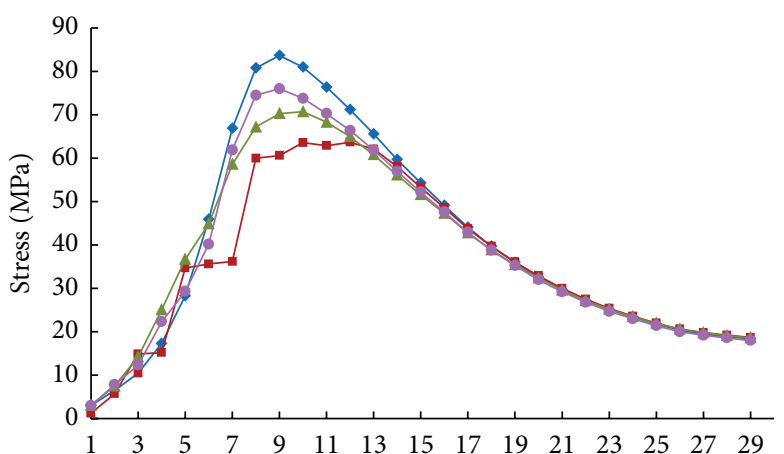

The distance between the monitoring points and working face $(\mathrm{m})$

$$
\begin{aligned}
& \longrightarrow \text { No blasting } \\
& \rightarrow \text { Blasting angle is } 30^{\circ} \rightarrow \text { Blasting angle is } 45^{\circ} \\
& - \text { Blasting angle is } 60^{\circ}
\end{aligned}
$$

FIgURE 2: The changing curve of side-abutment pressure.

(1) Properly applying DHPB can break the roof and effectively induce roof caving in the gob area. Also, it can weaken the integrity and continuity of the roof in the gob and ahead of the face, thus reducing the impact when roof pressure comes.

(2) The dynamic shattering and air pressure generated by the blasting can structurally change the properties of the coal-rock mass by mitigating the high stress generation and high elastic energy accumulation, thus breaking the conditions of energy transfer and rockburst occurrence at a certain degree.

\section{Case Study of DHPB Application}

4.1. Basic Geotechnical Conditions of Yuejin Mine. Yuejin coal mine was constructed and put into operation in 1959; it is attached to Yima Coal Industry Group and located $2 \mathrm{~km}$ to the south of Yima City, Henan Province. The mine geographical coordinates are $111^{\circ} 50^{\prime} 37^{\prime \prime} \sim 111^{\circ} 56^{\prime} 15^{\prime \prime}$ east longitude and $34^{\circ} 39^{\prime} 00^{\prime \prime} \sim 34^{\circ} 43^{\prime} 13^{\prime \prime}$ north latitude; the area is about $21.4 \mathrm{~km}^{2}$.

The mining method utilized by Yuejin mine is fully mechanized retreat longwall. The cover depth varies from $580 \mathrm{~m}$ to $1,030 \mathrm{~m}$. The overburden mainly consists of sandstone and hard conglomerate with a thickness of $400 \mathrm{~m}$ in average. Since the first rockburst occurred at face 25090 in 2000, the recorded bursting accidents are up to 40 times, causing entry damage as long as 2,500 $\mathrm{m}$ across the mine. Due to its strong
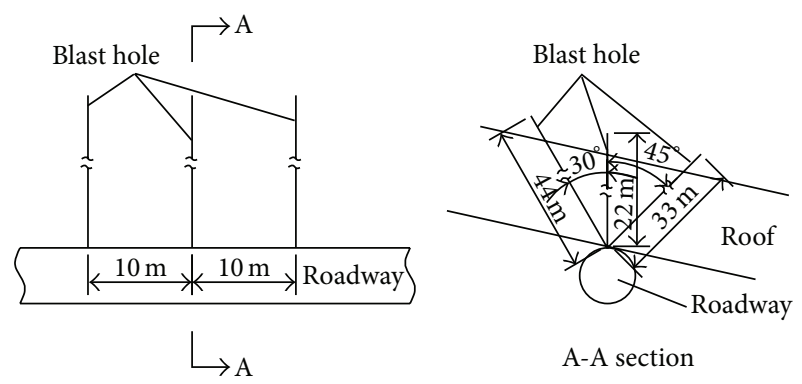

A-A section

Figure 3: The schematic diagrams of DHPB.

bursting proneness, the roof needs to be caved in a wellmanaged way.

4.2. Rockburst Prevention Test with DHPB. The precracking blasting testing site is located at the tailgate, $330 \mathrm{~m}$ away from the stop line of longwall 25110. Three stations of DHPB testing site were determined for deploying these blast holes, which are $285 \mathrm{~m}, 320 \mathrm{~m}$, and $345 \mathrm{~m}$ away from the longwall stop line, respectively. The spacing between these two adjacent stations is $10 \mathrm{~m}$. In a fan-shaped arrangement, three blast holes with a hole spacing of $10 \mathrm{~m}$ for each station were drilled perpendicularly to the entry (Figure 3 ). The drilling angles of these two side blast holes are $30^{\circ}$ and $45^{\circ}$ relative to the coal seam, respectively. The depths of these two side blast holes are, respectively, $44 \mathrm{~m}$ and $33 \mathrm{~m}$ while the middle one is $22 \mathrm{~m}$. The diameter of these blast holes is approximately $75 \mathrm{~mm}$.

In order to detect and examine the rockburst prevention effectiveness of DHPB, the cuttings weight, mining induced stress, and working resistance of the hydraulic support were monitored. The arrangement of monitoring locations is shown in Figure 4. The three cuttings weight measuring points were $285 \mathrm{~m}, 320 \mathrm{~m}$, and $345 \mathrm{~m}$ away from the terminal mining line. The two mining induced stress measuring points were $325 \mathrm{~m}$ and $345 \mathrm{~m}$ away from the terminal mining line. And the serial number of the 4 supports was $83,103,113$, and 123.

\subsection{Evaluation of Rockburst Prevention Effectiveness}

4.3.1. Cuttings Weight. Shown in Figure 5 are the cutting weights before and after the blasting from these three monitoring stations. It can be seen that the cutting weight obtained from the middle station greatly decreased after the blasting conducted on November 17 th. However, a minor change was 


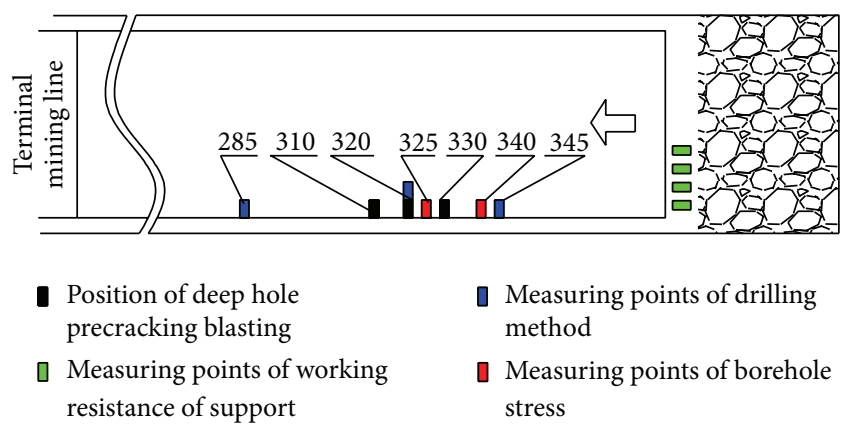

FIGURE 4: The arrangement of monitoring points.

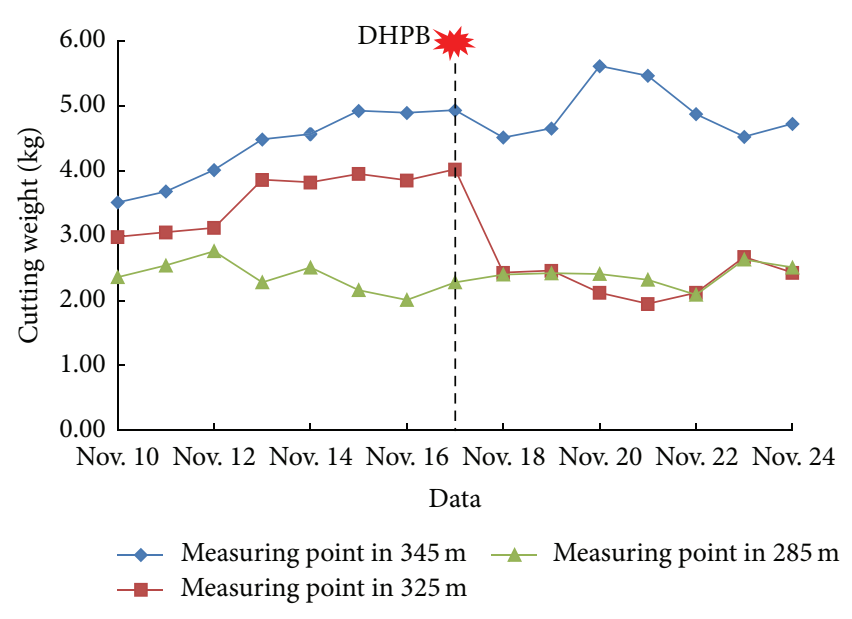

FIGURE 5: Cutting weight variation before and after blasting.

recorded in other two stations. Usually, there is a reliable correlation between the cutting weight of coal and the stress developed in the coal-rock mass. A decreasing cutting weight suggests the stress was relieved. It should be noted that the influence range of DHPB is not infinite. For the area that is out of the influence range, the cutting weight and stress developed in the coal-rock mass do not change much.

4.3.2. Mining Induced Stress. To monitor the vertical stress developed in the coal seam, two KSE-II borehole stress meters were installed at a distance of $325 \mathrm{~m}$ and $340 \mathrm{~m}$ apart away from the longwall stop line. The depth of the blast hole at $325 \mathrm{~m}$ is $12 \mathrm{~m}$ and the other one is $15 \mathrm{~m}$. The stress variation before and after blasting is shown in Figure 6. It can be seen that the stresses from both locations became much lower after the first blasting on November 11th. The lower stress developed in the surrounding rock of the entry greatly decreased the bursting proneness as expected. As indicated in Figure 6, the stress was getting higher after the blasting on November 20th due to the longwall mining activity, but its peak value is lower comparing with the one obtained before the blasting.

4.3.3. Working Resistance of Hydraulic Support. The major purpose of DHPB is to make the strong roof from hardto-cave to periodic caving as the longwall moves, reducing

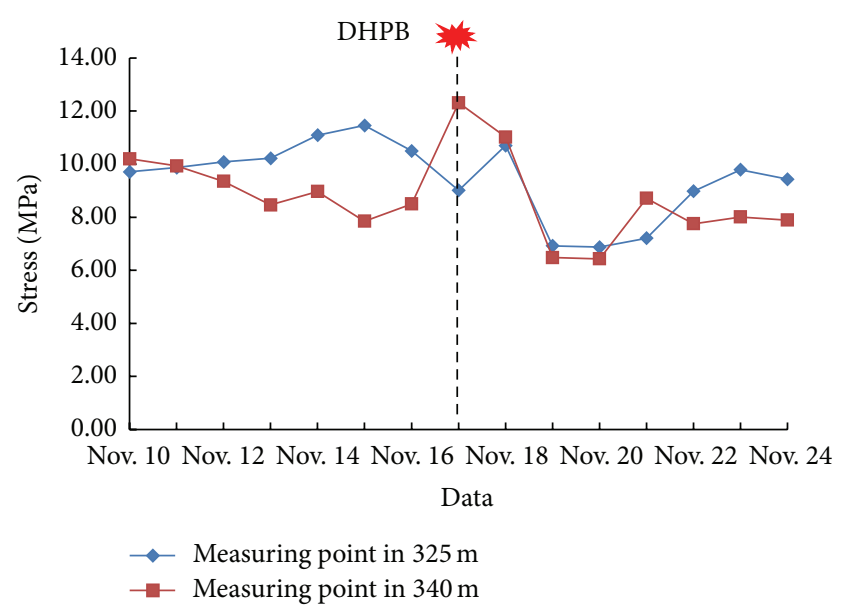

FIGURE 6: Borehole stresses variation before and after the blasting.

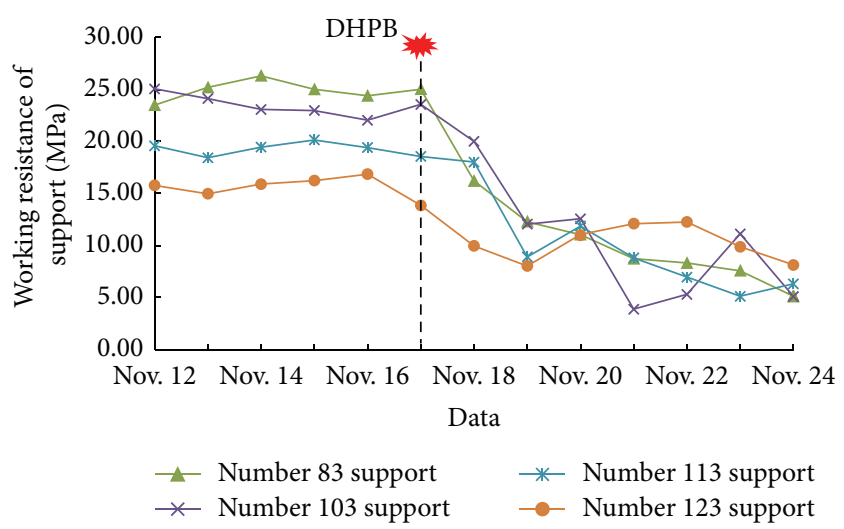

FIGURE 7: Working resistance variation of hydraulic supports before and after DHPB.

the span of the hanging roof and the pressure around the longwall face. Therefore, the pressure of the face support can be considered as another index indicating the effectiveness of DHPB.

There are 124 hydraulic supports installed in the longwall face 25110 of Yuejin mine. These supports were numbered from the head gate to the tailgate as $\# 1, \# 2, \ldots, \# 124$. As mentioned above, these blasting holes were drilled in the tailgate. When comparing the support resistances across the face, it can be seen that supports \#1 to \#80 experienced a minor pressure change while the rest evident. Figure 7 illustrates the working resistance variation of supports \#83, $\# 103$, \#113, and \#123, which are closer to the tailgate, before and after the blasting. The recorded working resistance evidently indicates the pressure greatly reduced after applying DHPB. For the support \# 83 , the pressure decreased by $73.6 \%$ from $25 \mathrm{MPa}$ to $6.6 \mathrm{MPa}$. Additionally, the field observation indicated that, when the shearer was approaching the tailgate, the vibration generated from the drum was not visible and no coal squeezed out from the face, indicating a lower pressure from both the roof and the floor. 


\section{Conclusions}

(1) Roof strata has a great influence on the bursting proneness of coal seam. The bursting proneness tests of pure coal and coal-rock mass complex showed that, comparing with the pure coal, the duration of dynamic fracture of coal-rock mass complex was decreased from $351 \mathrm{~ms}$ to $12.3 \mathrm{~ms}$, the elastic strain energy index was increased from 1.64 to 9.44 , the bursting energy index was increased from 2.63 to 5.53 , and the uniaxial compressive strength was increased from 12.98 $\mathrm{MPa}$ to 19.20 $\mathrm{MPa}$. The bursting proneness of coal-rock mass combination is evidently higher than pure coal or rock strata only. The thicker the strong roof stratum, the higher the bursting proneness of coal-rock. The combination of roof rock and coal, both with weak bursting proneness, can form a coal-rock mass complex with a strong bursting proneness.

(2) Properly applying DHPB can structurally break the original composition of the roof strata and coal, thus reducing its bursting proneness. The dynamic shattering and air pressure generated by the blasting can structurally change the properties of the coalrock mass by mitigating the high stress generation and high elastic energy accumulation, thus breaking the conditions of energy transfer and rockburst occurrence.

(3) The field testing data, including cutting weight, mining induced stress, working resistance of the hydraulic support, and microseismic events and energy from Yuejin coal mine, indicate that the stress concentration of coal-rock mass was greatly mitigated by DHPB. It can be conclusive that the approach of DHPB is applicable and reliable in reducing the bursting proneness for a burst-prone mine.

\section{Conflict of Interests}

The authors declare that there is no conflict of interests regarding the publication of this paper.

\section{Acknowledgments}

This work was financially supported by the State Key Development Program for Basic Research of China (Grant no. 2010CB226806), the International Science \& Technology Cooperation Program of China (2011DFA61790), and the National Natural Science Foundation of China (Grants nos. 51174272, 51174112, and 51304117).

\section{References}

[1] J. M. Alcott, P. K. Kaiser, and B. P. Simser, "Use of microseismic source parameters for rockburst hazard assessment," Pure and Applied Geophysics, vol. 152, no. 1, pp. 41-65, 1998.

[2] J. Dubinski and W. Konopko, Rockbursts-Assessment, Prediction and Control-Working Rules, Central Mining Institute, Katowice, Poland, 2000 (Polish).
[3] A. C. Adoko, C. Gokceoglu, L. Wu, and Q. J. Zuo, "Knowledgebased and data-driven fuzzy modeling for rockburst prediction," International Journal of Rock Mechanics and Mining Sciences, vol. 61, pp. 86-95, 2013.

[4] Y. Wang, W. Li, and Q. Li, "Method of fuzzy comprehensive evaluations for rockburst prediction," Chinese Journal of Rock Mechanics and Engineering, vol. 17, pp. 493-501, 1998.

[5] Y.-H. Guo and F.-X. Jiang, "Application of comprehensive fuzzy evaluation in burst-proneness risk of coal seam," in Proceedings of the 2nd International Conference on Future Information Technology and Management Engineering (FITME '09), pp. 404407, December 2009.

[6] F.-Q. Gong, X.-B. Li, and W. Zhang, "Rockburst prediction of underground engineering based on Bayes discriminant analysis method," Rock and Soil Mechanics, vol. 31, no. 1, pp. 370-387, 2010.

[7] X. Z. Shi, J. Zhou, L. Dong, H. Y. Hu, H. Wang, and S. R. Chen, "Application of unascertained measurement model to prediction of classification of rockburst intensity," Chinese Journal of Rock Mechanics and Engineering, vol. 29, no. 1, pp. 2720-2726, 2010.

[8] H. Li, R.-Z. Dai, and J.-Q. Jiang, "Predicting Model of rock burst based on Lyapunov index," Journal of Mining and Safety Engineering, vol. 23, pp. 215-219, 2006 (Chinese).

[9] J. Zeng, Y.-X. Zhang, and X.-G. Jin, "Prediction of rock burst using the method of optimal relative membership degree based on the maximum entropy principle," Journal of Civil, Architectural and Environmental Engineering, vol. 33, no. 1, pp. 93-97, 2011.

[10] H.-C. Yu, H.-N. Liu, L. U. Xue-song, and H.-D. Liu, "Prediction method of rock burst proneness based on rough set and genetic algorithm," Journal of Coal Science and Engineering (China), vol. 15, no. 4, pp. 367-373, 2009.

[11] X. Chen, J. Sun, J. Zhang, and Q. Chen, "Judgment indexes and classification criteria of rock-burst with the extension judgment method," China Civil Engineering Journal, vol. 42, no. 9, pp. 8288, 2009.

[12] G. Takla, J. Ptacek, J. Holecko, and P. Konicek, "Stress state determination and prediction in rock mass with rockburst risk in Ostrava-Karvina coal basin," in Proceedings of the International Symposium of the International Society for Rock Mechanics (Eurock '05), pp. 625-628, Brno, Czech Republic, May 2005.

[13] J.-L. Yang, X. B. Li, Z.-L. Zhou, and H. Lin, "A fuzzy assessment method of rockburst prediction based on rough set theory," Metal Mine, vol. 408, pp. 26-29, 2010.

[14] C. Srinivasan, S. K. Arora, and R. K. Yaji, "Use of mining and seismological parameters as premonitors of rockbursts," International Journal of Rock Mechanics and Mining Sciences, vol. 34, no. 6, pp. 1001-1008, 1997.

[15] L.-Z. Tang and K. W. Xia, "Seismological method for prediction of areal rockbursts in deep mine with seismic source mechanism and unstable failure theory," Journal of Central South University of Technology, vol. 17, no. 5, pp. 947-953, 2010.

[16] K. Holub, J. Rušajová, and J. Holečko, "Particle velocity generated by rockburst during exploitation of the longwall and its impact on the workings," International Journal of Rock Mechanics and Mining Sciences, vol. 48, no. 6, pp. 942-949, 2011.

[17] Z. H. Ouyang, "Mechanism and experiment of hydraulic fracturing in rock burst prevention," in Proceedings of the 1st International Conference on Rock Dynamics and Applications (RocDyn-1 '13), pp. 245-250, Lausanine, Switzerland, June 2013. 
[18] P. Konicek, K. Soucek, L. Stas, and R. Singh, "Long-hole destress blasting for rockburst control during deep underground coal mining," International Journal of Rock Mechanics and Mining Sciences, vol. 61, pp. 141-153, 2013.

[19] P. Konicek, P. Konecny, and J. Ptacek, "Destress rock blasting as a rockburst control technique," in Proceedings of the 12th International Congress on Rock Mechanics of the International Society for Rock Mechanics (ISRM '11), pp. 1221-1226, Bejing, China, October 2011.

[20] P. Konicek, M. R. Saharan, and H. Mitri, "Destress blasting in coal mining - state-of-the-art review," in Proceedings of the 1st International Symposium on Mine Safety Science and Engineering (ISMSSE '11), pp. 179-194, Beijing, China, October 2011.

[21] P. Dvorsky, P. Konicek, E. Morkovska, and L. Palla, "Rock blasting as a rockburst control measures in the safety pillar of SW crosscuts at Lazy Colliery in Orlová," in Proceedings of the 10th International Scientific-Technical Conference-Rockbursts, pp. 37-45, Ustroń, Poland, November 2003.

[22] P. Dvorsky and P. Konicek, "Systems of rock blasting as a rockburst measure in the Czech part of Upper Silesian Coal Basin," in Proceedings of the 6th International Symposium on Rockburst and Seismicity in Mines, pp. 493-496, Perth, Australia, March 2005.

[23] A. Przeczek, P. Dvorsky, and P. Konicek, "System of rock blasting in boreholes diameter more than $100 \mathrm{~mm}$ as a rock burst measure," in Proceedings of the 12th International ScientificTechnical Conference-Rockbursts, pp. 253-269, Ustroń, Poland, 2005.

[24] P. Konicek and A. Przeczek, "Study of selected cases of local stress reduction due to rock blasting," in Proceedings of the 15th International Scientific-Technical Conference (GZN'08), pp. 143161, Targanice, Poland, November 2008.

[25] H. He, L. Dou, J. Fan, T. Du, and X. Sun, "Deep-hole directional fracturing of thick hard roof for rockburst prevention," Tunnelling and Underground Space Technology, vol. 32, pp. 34-43, 2012. 

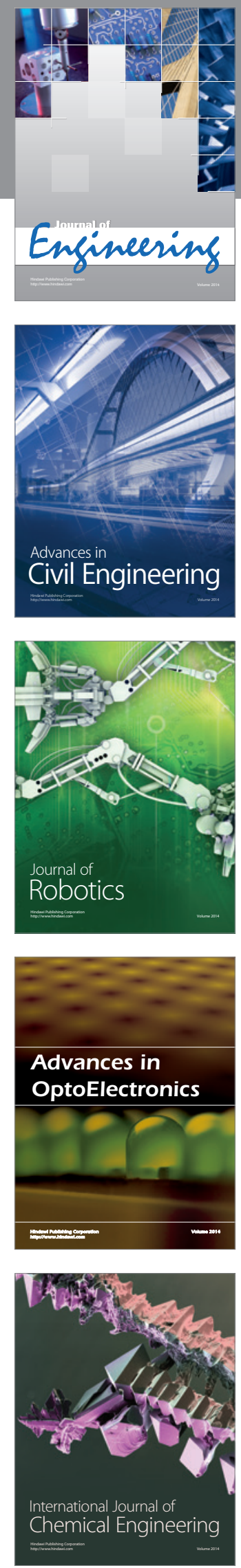

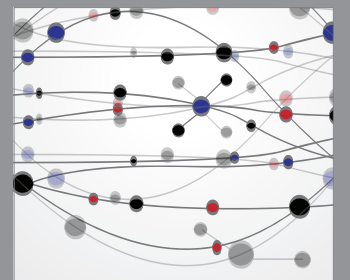

The Scientific World Journal
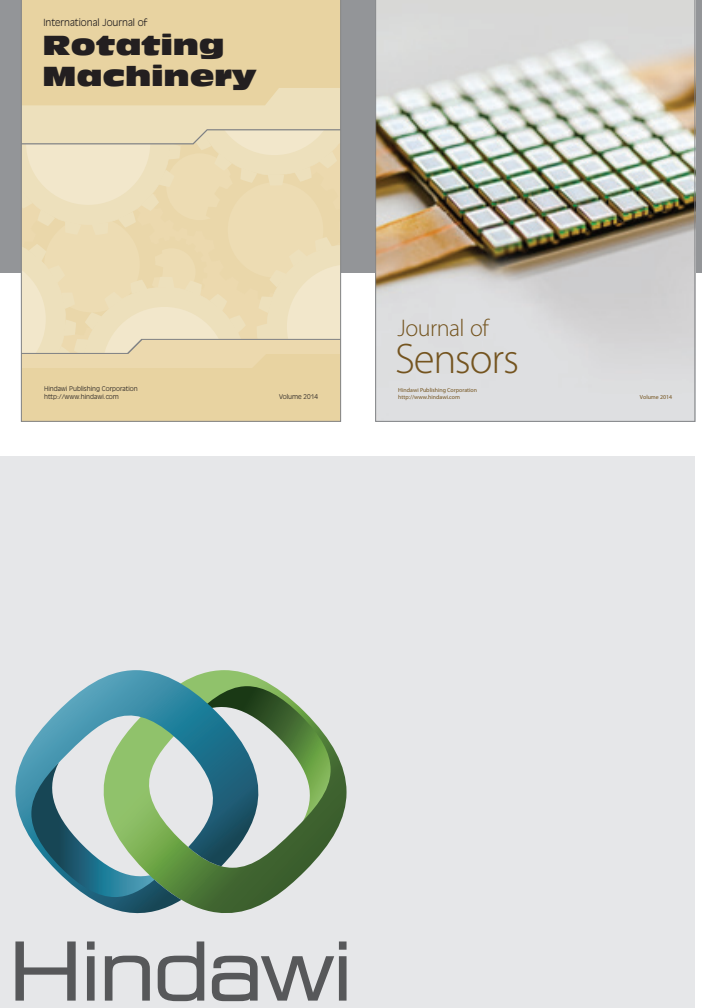

Submit your manuscripts at http://www.hindawi.com
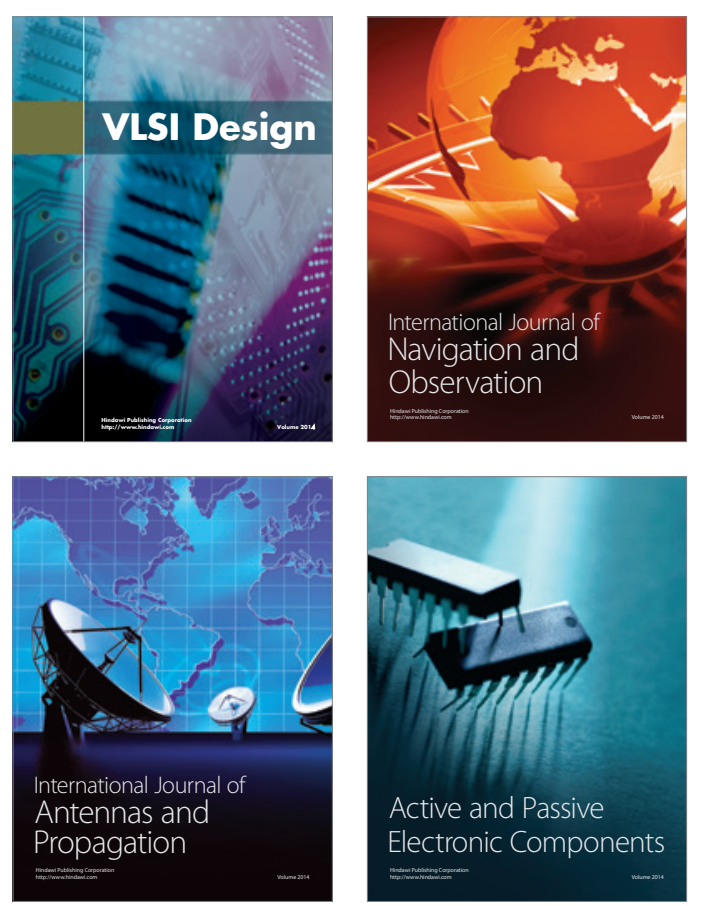
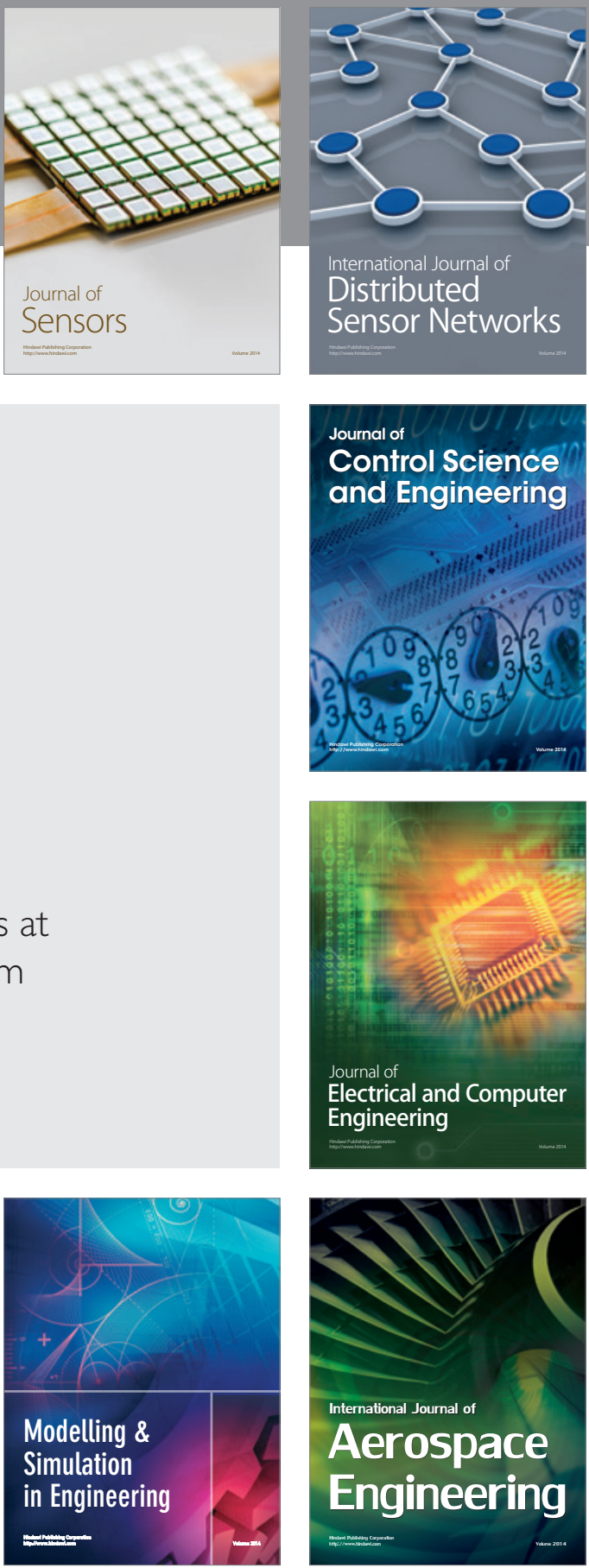

Journal of

Control Science

and Engineering
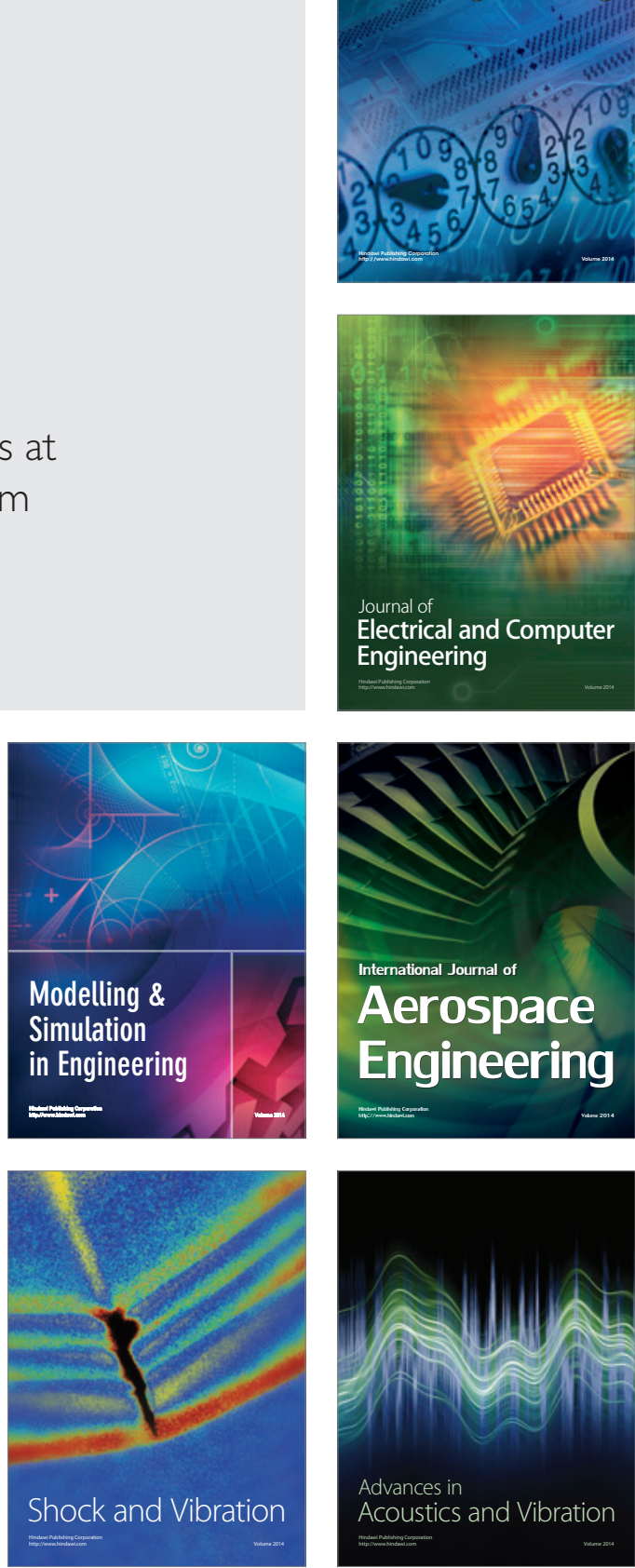